\title{
Clostridium cellulolyticum sp. nov., a Cellulolytic, Mesophilic Species from Decayed Grass
}

\author{
E. PETITDEMANGE, ${ }^{1 *}$ F. CAILLET,${ }^{1}$ J. GIALLO,${ }^{2}$ AND C. GAUDIN ${ }^{2}$ \\ Université de Nancy 1, Laboratoire de Chimie Biologique 1, Vandoeuvre-les-Nancy Cédex, France and Laboratoire de \\ Chimie Bactérienne, Centre National de la Recherche Scientifique, Marseille Cédex 9, France ${ }^{2}$
}

\begin{abstract}
A new cellulolytic Clostridium species that was isolated from decayed grass is described. The colonies produced by this organism on cellulose agar are circular, translucent, and unpigmented and have undulate margins. The cells of this bacterium are gram-positive straight to slightly curved rods 3 to $6 \mu \mathrm{m}$ long by 0.6 to $1 \mu \mathrm{m}$ wide and are motile; they form round, terminal spores $1.5 \mu \mathrm{m}$ in diameter. A variety of carbohydrates are fermented by this mesophilic anaerobe. The major fermentation products from cellulose are carbon dioxide, hydrogen, ethanol, acetate, lactate, and formate. The deoxyribonucleic acid base composition is $41 \mathrm{~mol} \%$ guanine plus cytosine. The type strain of Clostridium cellulolyticum sp. nov. is strain $\mathrm{H}_{10}(=$ ATCC 35319).
\end{abstract}

Anaerobic cellulolytic bacteria that take part in the degradation of cellulosic materials have been isolated from manure, rumen contents, and soil. In this report we describe the isolation and characterization of a new species of Clostridium from compost.

\section{MATERIALS AND METHODS}

Media and culture techniques. The composition of the medium which we used was the same as the composition of the cellulose-yeast extract-salts medium (CM medium) described by Weimer and Zeikus (15), except that $\mathrm{Na}_{2} \mathrm{~S}$ was omitted, the cysteine hydrochloride concentration was 1 $\mathrm{g} /$ liter, and the cellulose MN300 concentration was 7.5 g/liter.

For solid media CM medium was supplemented with $20 \mathrm{~g}$ of agar (Difco Laboratories, Detroit, Mich.) per liter. The $\mathrm{pH}$ was adjusted to 7.5 with $\mathrm{NaOH}$. This medium was prereduced by the Hungate technique (5) and was dispensed under a constant flow of $\mathrm{N}_{2}$ in $8-\mathrm{ml}$ amounts $(4.5-\mathrm{ml}$ amounts for solid medium) into anaerobic culture tubes (16 by 125 mm; Bellco Glass, Inc., Vineland, N.J.).

For enrichment cultures, we used anaerobic tubes ( 25 by $142 \mathrm{~mm}$; Bellco) that contained $25 \mathrm{ml}$ of medium.

Carbohydrate media were prepared by replacing cellulose with filter-sterilized solutions of carbohydrates to give final concentrations of $7.5 \mathrm{~g} /$ liter. The cultures were incubated at $35^{\circ} \mathrm{C}$ without shaking.

The anaerobic culture techniques of Hungate (5), as modified by Bryant (1), were used throughout this work.

All cultures were inoculated and incubated with nitrogen as the gas.

Isolation of strain $\mathbf{H}_{10}{ }^{\mathrm{T}}$. Strain $\mathrm{H}_{10}{ }^{\mathrm{T}}$ ( $\mathrm{T}=$ type strain) was obtained from cultured decayed grass by enrichment and isolation.

Enrichment cultures were initiated by inoculating 1 to $2 \mathrm{~g}$ of grass from compost into anaerobic culture tubes ( 25 by $142 \mathrm{~mm}$; Bellco) containing $25 \mathrm{ml}$ of prereduced medium. After 1 week of incubation at $35^{\circ} \mathrm{C}$, the cultures were heated at $80^{\circ} \mathrm{C}$ for $10 \mathrm{~min}$, and $1 \mathrm{ml}$ of each culture was then transferred to $8 \mathrm{ml}$ of prereduced liquid medium.

After a few days of incubation, cultures that produced

\footnotetext{
* Corresponding author
}

discrete gas bubbles and solubilized cellulose were selected for isolation in solid medium.

Serial dilutions were incubated in cellulose agar roll tubes. After 3 to 5 days, colonies which produced cleared zones of cellulose digestion were transferred individually into the liquid medium by means of a bent Pasteur pipette (5) under a flow of $\mathrm{N}_{2}$ gas.

Electron microscopy. A colony was picked from cellulose agar. The cells were fixed with $2 \%$ osmic acid, suspended in agar, (Difco), dehydrated, and embedded in Epon. Thin sections were cut with a diamond knife and were contrasted with lead citrate.

The sections were viewed with a Siemens Elmiskop model 102 electron microscope.

Isolation of DNA and measurement of the $G+C$ content of the DNA. Deoxyribonucleic acid (DNA) was isolated by the method of Marmur (10).

The DNA base composition, expressed as the guanineplus-cytosine $(G+C)$ content, was estimated from the thermal denaturation temperature, which was determined by the method of Marmur and Doty (11).

Thermal denaturation of DNA was carried out with a Perkin-Elmer model 551 spectrophotometer equipped with a temperature program controller.

The absorbance changes at $260 \mathrm{~nm}$ were recorded, and the values were corrected by the method of Mandel and Marmur (9).

The $\mathrm{G}+\mathrm{C}$ content was calculated from the thermal denaturation temperature by using the following equation of Marmur and Doty (11): $\mathrm{G}+\mathrm{C}$ content $=2.44 \times$ (thermal denaturation temperature - 69.3).

Biochemical tests. Biochemical tests were performed by the standard procedures described in the Anaerobe Laboratory Manual (3). Tests were read after 3 days and again after 10 days.

Growth measurements. For determinations of growth rates on carbohydrates, the optical densities at $525 \mathrm{~nm}$ were measured with a Beckman model 25 spectrophotometer. For growth on cellulose, the pellet proteins were determined by the method of Gordon et al. (2), and the total protein was estimated by the method of Lowry et al. (7), using bovine serum albumin (Sigma Chemical Co., St. Louis, Mo.) as the standard.

Analytical methods. The composition of the gas in the headspace was analyzed. $\mathrm{H}_{2}$ and $\mathrm{CO}_{2}$ were determined by 

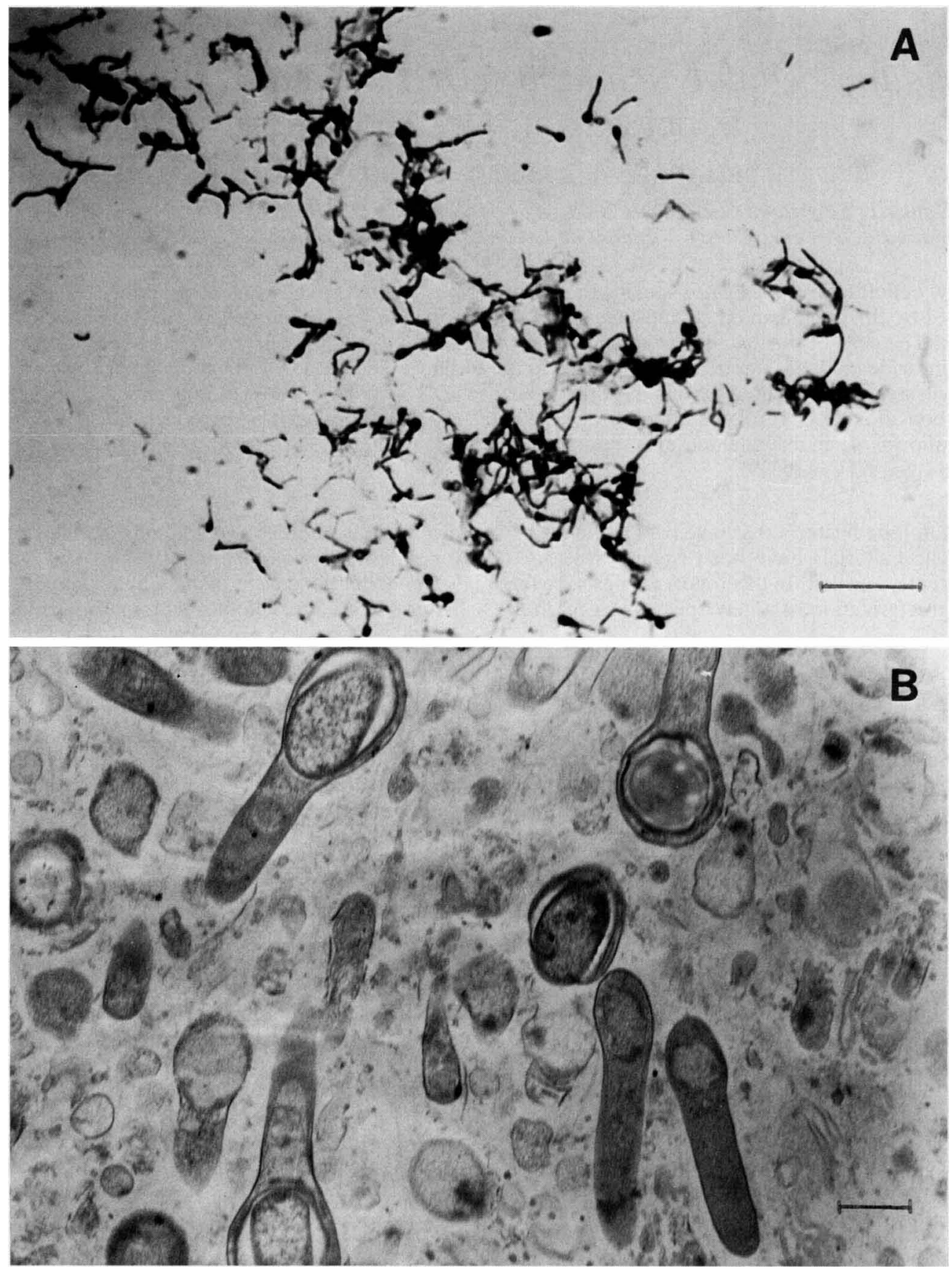

FIG. 1. C. cellulolyticum. (A) Vegetative and sporulated cells of strain $\mathrm{H}_{10}{ }^{\mathrm{T}}$ grown on medium containing cellulose $\mathrm{MN} 300$. Bar $=10 \mu \mathrm{m}$. (B) Ultrathin section of vegetative and sporulated cells. Bar $=1 \mu \mathrm{m}$.

using an Intersmat model IGC MB chromatograph equipped with a thermoconductivity detector $(80 \mathrm{~mA})$ and a column $(2$ $\mathrm{m}$ by $2 \mathrm{~mm}$ [inside diameter]) fitted with Carbosieve (120140 mesh; Supelco). The column temperature was $100^{\circ} \mathrm{C}$, and the carrier gas was argon (1.8 to 2 bars at the column head).

The injection temperature was $130^{\circ} \mathrm{C}$ and the detector temperature was $110^{\circ} \mathrm{C}$. A $0.5-\mathrm{ml}$ sample of the culture gas phase was injected directly into the gas chromatography apparatus by means of a $1-\mathrm{ml}$ syringe.

Culture samples were centrifuged at $25,000 \times g$ for $10 \mathrm{~min}$. The resulting supernatant was retained for a determination of alcohols and acids, and the pellet was used to determine the pellet protein.

Alcohols and volatile fatty acids were analyzed by using a Carlo-Erba Fractovap model G1 gas chromatograph. This instrument was equipped with a flame ionization detector. The column was made of stainless steel, was 2 meters long and $5 \mathrm{~mm}$ in diameter, and contained Porapak Q (100-120 mesh; Waters Associates, Milford Mass.).

The following conditions were selected for this analysis: column temperature, $220^{\circ} \mathrm{C}$; carrier gas, nitrogen ( 1 bar); injector temperature, $240^{\circ} \mathrm{C}$; carrier gas flow rate, 10 $\mathrm{cm}^{3} / \mathrm{min}$; hydrogen and air flow rate, $160 \mathrm{~cm}^{3} / \mathrm{min}$. 


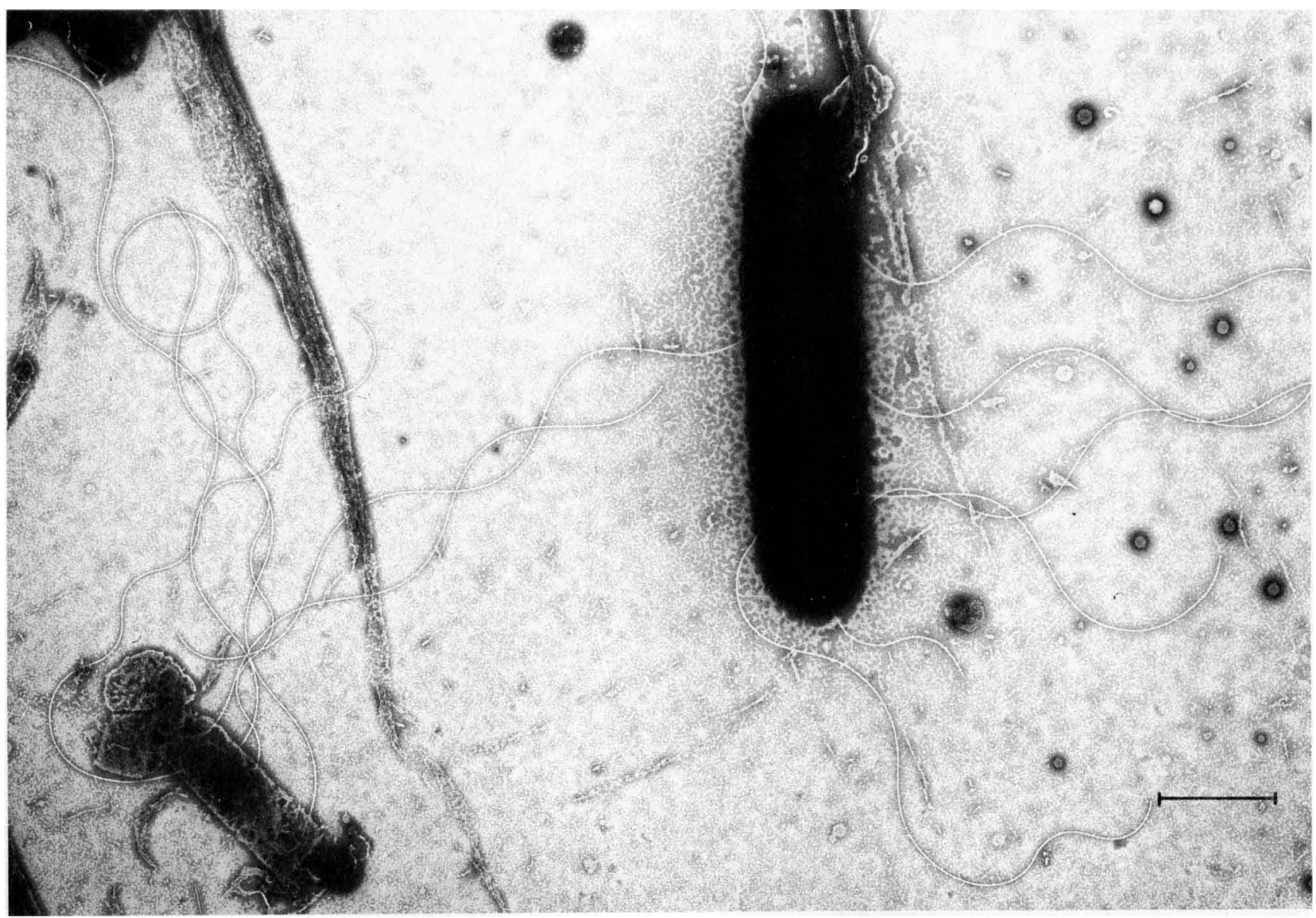

FIG. 2. Electron micrograph of $C$. cellulolyticum. Bar $=1 \mu \mathrm{m}$.

A 1-ml culture supernatant sample was acidified with $50 \mu \mathrm{l}$ of $6 \mathrm{~N} \mathrm{HCl}$, and $2 \mu \mathrm{l}$ of the acidified supernatant was injected into the gas chromatograph.

L(-)-Lactate was determined enzymatically by using a lactate dehydrogenase-based kit (Boehringer-Mannheim Gmbh, Biochemica, Mannheim, West Germany).

Formate was determined by the colorimetric method of Lang and Lang (6).

The total reducing sugars in the supernatant were determined by using a dinitrosalicylic acid reagent with glucose as the standard and the method of Miller et al. (12).

Glucose was determined enzymatically with glucose oxidase (Boehringer-Mannheim).

\section{RESULTS AND DISCUSSION}

Our isolate from cellulose enrichment cultures of compost appears to be a new species that belongs in Clostridium group III, as described by Smith and Hobbs (14). A description of this species is given below.

Clostridium cellulolyticum sp. nov. Clostridium cellulolyticum (cel.lu.lo.ly'ti.cum. Gr. n. cellulosum cellulose; Gr. adj. lyticus dissolving; N.L. adj. cellulolyticum cellulose dissolving) cells (Fig. 1) are anaerobic, gram-positive, straight to slightly curved rods that are 3 to $6 \mu \mathrm{m}$ long by 0.6 to $1 \mu \mathrm{m}$ wide. Spores are present in cultures on cellulose media 3 or more days old; these spores are spherical (diameter, $1.5 \mu \mathrm{m}$ ) and terminal, produce swollen cells (Fig. $1 \mathrm{~A}$ and $\mathrm{B}$ ), and resist a temperature of $100^{\circ} \mathrm{C}$ for $30 \mathrm{~min}$.
Spores are rarely formed on other carbohydrate media. The cells are motile by means of peritrichous flagella (Fig. 2) and have a cell wall that is typical of the cell walls of grampositive species.

On cellulose agar medium colonies appear after 5 to 6 days of incubation at $35^{\circ} \mathrm{C}$. Surface colonies are smooth, circular, approximately $0.5 \mathrm{~mm}$ in diameter, slightly raised, translucent, and unpigmented with undulate margins, and a butyrous texture. Clear zones showing complete solubilization of cellulose around the colonies are 1 to $4 \mathrm{~mm}$ in diameter.

The maximum growth temperature is $45^{\circ} \mathrm{C}$, the optimum growth temperature is 32 to $35^{\circ} \mathrm{C}$, and the minimum growth temperature is $25^{\circ} \mathrm{C}$; growth does not occur at 20 and $50^{\circ} \mathrm{C}$ even after 2 months.

There is no growth with adonitol, amygdalin, dulcitol, erythritol, glycerol, glycogen, inositol, inulin, lactose, maltose, mannitol, melezitose, raffinose, rhamnose, salicin, sorbitol, sorbose, sucrose, and trehalose.

Poor growth is produced with galactose, mannose, or ribose.

Moderate growth is produced with arabinose, cellobiose, cellulose, fructose, glucose, and xylose, and the final $\mathrm{pH}$ is 5.5 to 5.2. The doubling times with cellobiose, cellulose, and glucose are 7,15 , and $10 \mathrm{~h}$, respectively.

Esculin is hydrolyzed; starch is not hydrolyzed. Ammonia is not produced from arginine. Acetylmethylcarbinol, nitrite, and indole are not produced. Milk is unchanged, casein is not digested, and no growth occurs in chopped meat broth. Pyruvate and lactate are not utilized. Gelatin is not liquefied, 
TABLE 1. Principal differences that distinguish C. cellulolyticum, C. cellobioparum, and C. papyrosolvens

\begin{tabular}{|c|c|c|c|c|c|c|}
\hline \multirow{2}{*}{ Characteristic } & \multicolumn{4}{|c|}{ C. cellobioparum as described by: } & \multirow{2}{*}{ C. papyrosolvens ${ }^{e}$} & \multirow{2}{*}{ C. cellulolyticum } \\
\hline & Hungate $^{a}$ & Skinner ${ }^{b}$ & Smith and $\mathrm{Hobbs}^{c}$ & Anaerobe Laboratory Manual ${ }^{d}$ & & \\
\hline \multicolumn{7}{|c|}{ Carbohydrate fermentation } \\
\hline Dulcitol & $\mathrm{ND}^{f}$ & ND & +8 & + & - & - \\
\hline Esculin & ND & ND & - & $-(\mathrm{pH})^{h}$ & + & $-(\mathrm{pH})^{h}$ \\
\hline Galactose & $\mathrm{S}$ & w & + & + & + & w \\
\hline Glucose & + & $\mathrm{w}$ & + & + & + & + \\
\hline Glycerol & - & - & w & w & + & - \\
\hline Lactose & $\mathbf{S}$ & w & w & $\mathbf{w}$ & - & - \\
\hline Maltose & + & + & + & + & - & - \\
\hline Mannitol & $\mathbf{S}$ & - & w & w & - & - \\
\hline Mannose & + & + & + & + & - & w \\
\hline Melibiose & + & ND & + & + & - & - \\
\hline Raffinose & $\mathrm{S}$ & - & + & w & - & - \\
\hline Ribose & ND & ND & + & + & + & S \\
\hline Salicin & - & - & + & w & - & - \\
\hline Sucrose & $\mathrm{S}$ & - & - & - & - & - \\
\hline Sorbitol & ND & ND & + & w & - & - \\
\hline $\mathrm{G}+\mathrm{C}$ content $(\mathrm{mol} \%)$ & ND & ND & 25 & 28 & 30 & 41 \\
\hline Gram reaction & ND & - & - & - & - & + \\
\hline
\end{tabular}

${ }^{a}$ See reference 4.

${ }^{b}$ See reference 13

${ }^{c}$ See reference 14

${ }^{d}$ See reference 3 .

e See reference 8 .

${ }^{f} \mathrm{ND}$, Not determined.

$g+$, Positive; -, negative; w, weakly fermented; S, occasionally slowly fermented.

${ }^{h}$ Hydrolysis occurs with no change in the $\mathrm{pH}$ value.

and thiosulfate is not reduced. Catalase, urease, lipase, and lecithinase are not produced.

Carbon dioxide, hydrogen, acetate, ethanol, lactate, and formate are produced from cellulose. Little glucose is detected among the reducing sugars produced.

Isolated in autumn from decayed grass compost packed for 3 to 4 months. The mean $\mathrm{G}+\mathrm{C}$ content of the DNA is 41 mol\%. The type strain is strain $\mathrm{H}_{10}$ (= ATCC 35319).

In Bergey's Manual of Determinative Bacteriology, 8th ed. (14), the only member of the group III clostridia that is recognized as cellulolytic is Clostridium cellobioparum.

The most significant differences between $C$. cellulolyticum and $C$. cellobioparum are shown in Table $1 . C$. cellulolyticum differs from $C$. cellobioparum in not fermenting dulcitol, lactose, mannose, and sorbitol. Furthermore, from cellulose digestion $C$. cellobioparum forms only cellobiose, the strain isolated by Skinner (13) forms glucose and little or no cellobiose, and our isolate forms cellobiose and little glucose.

C. cellulolyticum also differs from Clostridium papyrosolvens, a new species described by Madden et al. (8), in not fermenting glycerol and particularly in being unable to grow at temperatures below $25^{\circ} \mathrm{C}$. Finally, the $\mathrm{G}+\mathrm{C}$ content of the DNA of $C$. papyrosolvens is $30 \mathrm{~mol} \%$; thus, this species can be readily distinguished from $C$. cellulolyticum, which has a $\mathrm{G}+\mathrm{C}$ content of $41 \mathrm{~mol} \%$.

\section{ACKNOWLEDGMENTS}

This research was funded by the Solar Energy Program of the Centre National de la Recherche Scientifique (PIRSEM).

We express our gratitude to G. Raval for skillful technical assistance. We thank G. Kilbertus (University of Nancy I) for preparing and taking the electron micrograph of an ultrathin section and Pierre Thomas (Laboratoire de Différenciation Cellulaire du Centre Universitaire de Luminy) for the other electron micrographs.

\section{LITERATURE CITED}

1. Bryant, M. P. 1972. Commentary on the Hungate technique for culture of anaerobic bacteria. Am. J. Clin. Nutr. 25:1324-1328.

2. Gordon, J., M. Jiminez, C. L. Cooney, and D. I. C. Wang. 1978. Sugar accumulation during enzyme hydrolysis and fermentation of cellulose. AIChE Symp. Ser. 74:91-97.

3. Holdeman, L. V., E. P. Cato, and W. E. C. Moore, (ed.). 1977. Anaerobe laboratory manual, 4th ed. Anaerobe Laboratory, Virginia Polytechnic Institute and State University, Blacksburg.

4. Hungate, R. E. 1944. Studies on cellulose fermentation. I. The culture and physiology of an anaerobic cellulose-digesting bacterium. J. Bacteriol. 48:499-513.

5. Hungate, R. E. 1969. A roll tube method for cultivation of strict anaerobes, p. 117-132. In J. R. Norris and D. W. Ribbons (ed.). Methods in microbiology, vol. 3b. Academic Press, Inc., London.

6. Lang, E., and H. Lang. 1972. Spezifische Farbreaktion zum direkten Nachweis der Ameisensaüre. Fresenius Z. Anal. Chem. 260:8-10.

7. Lowry, O. H., N. J. Rosebrough, A. L. Farr, and R. J. Randall. 1951. Protein measurement with the Folin phenol reagent. J. Biol. Chem. 193:265-275.

8. Madden, R. H., M. J. Bryder, and N. J. Poole. 1982. Isolation and characterization of an anaerobic, cellulolytic bacterium, Clostridium papyrosolvens sp. nov. Int. J. Syst. Bacteriol. 32:87-91.

9. Mandel, M., and J. Marmur. 1968. Use of ultraviolet absorbance temperature profile for determining the guanine plus cytosine content of DNA. Methods Enzymol. 12B:195-206.

10. Marmur, J. 1961. A procedure for the isolation of deoxyribonucleic acid from microorganisms. J. Mol. Biol. 3:208-218.

11. Marmur, J., and P. Doty. 1962. Determination of the base composition of deoxyribonucleic acid from its thermal denaturation point. J. Mol. Biol. 5:109-118.

12. Miller, G. L., R. Blum, W. E. Glennon, and A. L. Burton. 1960. Measurement of carboxymethylcellulase activity. Anal. Biochem. 2:127-132.

13. Skinner, F. A. 1960. The isolation of anaerobic cellulose decomposing bacteria from soil. J. Gen. Microbiol. 2:539-554. 
14. Smith, L. DS., and G. Hobbs. 1974. Genus III. Clostridium, p 551-572. In R. E. Buchanan and N. E. Gibbons (ed.), Bergey's manual of determinative bacteriology, 8th ed. The Williams \& Wilkins Co., Baltimore.
15. Weimer, P. J., and J. G. Zeikus. 1977. Fermentation of cellulose and cellobiose by Clostridium thermocellum in the absence and presence of Methanobacterium thermoautotrophicum. Appl. Environ. Microbiol. 33:289-297. 